\title{
V. めまい，ふらつき，しびれ感，不眠症
}

\section{3. 高齢者睡眠障害の特徵とその対策}

\section{鈴木 圭輔 宮本 雅之 平田 幸一}

要旨

高齢者では加齢に伴う変化として, 若年者と比べて睡眠相が前進する. 睡眠構築では深睡眠が減少し， 浅い睡眠となり，その結果中途覚醒，早朝覚醒は増加する．また高齢者では様々な原因で不眠を起こす場 合があり, 生活の質を低下させる要因となる。そのため, まず治療可能な身体疾患や薬物の関与, 原発性 睡眠障害（睡眠時無呼吸症候群，レストレスレッグス症候群，レム睡眠行動異常症）の合併の評価を行う ことが重要である.

〔日内会誌 $103 ： 1885 \sim 1895,2014 〕$

Key words 高齢者, 不眠症, 原発性睡眠障害, 睡眠衛生, 睡眠薬

はじめに

睡眠障害は夜間の様々な訴えや障害に関連し, 睡眠時無呼吸症候群, レム睡眠行動異常症など の睡眠時随伴症, レストレスレッグス症候群な どの睡眠時運動関連疾患, 日中の覚醒障害であ る過眠症を含む. 本邦における調査では 5 人に 1 人が何らかの不眠を有すると報告されている1). 不眠は夜型化に伴い睡眠時間の減少している本 邦の現代社会ではいずれの年齢層においても, 頻度の高い重要な問題である.

不眠は睡眠に関する自覚的な訴えであり，睡 眠障害国際分類第 2 版では, 夜間の睡眠障害が 持続し, 睡眠の機会が十分であるのにもかかわ らず，日中の障害を来す場合を「不眠症」と定
義している2). 臨床的に用いられる不眠症は睡眠 障害国際分類第 2 版の精神生理性不眠症, 逆説 性不眠症, 特発性不眠症を合わせた概念に相当 し，それは米国精神医学会によるDSM-IV-TR (Diagnostic and Statistical Manual of Mental Disorders, Fourth Edition, Text Revision）の定 義する原発性不眠症に一致する。精神生理性不 眠症は不眠に対する恐怖などを契機に発症する 代表的な不眠症であり，睡眠に関する不安，就 寝時の身体的緊張や精神的覚醒を認める. 逆説 性不眠症は睡眠状態の誤認であり, 客観的な睡 眠障害が明らかでなく, 睡眠不足に相応する日 中障害がないにも関わらず，重度の不眠を訴え ることを特徵とする. 高齢者では特に，まず不 眠を引き起こす身体・精神疾患がないかどうか の鑑別は重要である。不眠症は眠れないことに

\section{獨協医科大学神経内科}

Neurological Common Diseases in the Super-Elder Society. Topics:V. Dizziness, Faintness, Numbness and Insomnia; 3. Characteristics and treatment of sleep disorders in the elderly.

Keisuke Suzuki, Masayuki Miyamoto and Koichi Hirata : Department of Neurology, Dokkyo Medical University, Japan. 


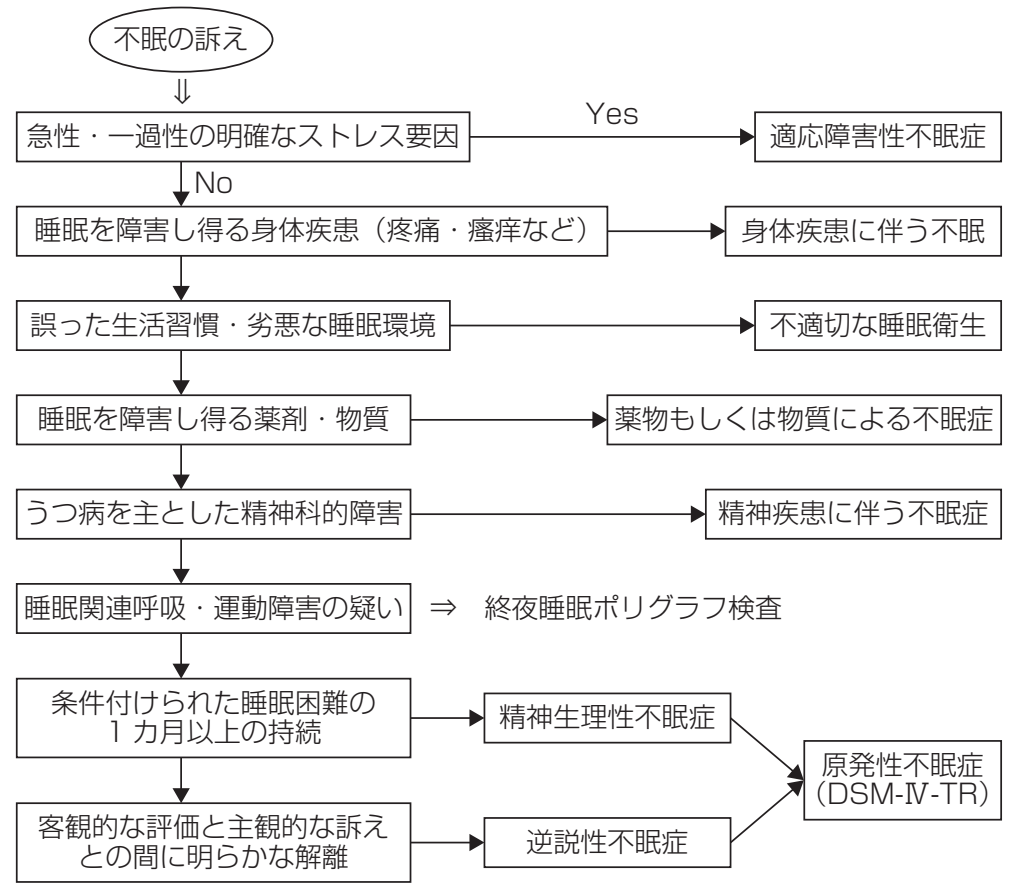

図 1. 不眠症の診断ガイドライン（文献 3 より引用）

よる日中の眠気や倦总感を引き起こすばかりで なく，原因疾患によっては未治療の場合，生命 予後に影響を及ぼす場合もあり，その原因検索 が重要である。うつ病による不眠は自殺予防の 観点から, 睡眠時無呼吸症候群による不眠は心 血管イベントや日中の眠気による事故予防の観 点から第一に鑑別すべき疾患である。ささらに不 眠は抑うつ症状や身体への影響として高血圧や 肥満とも関連する，従って，不眠をきたす原因 を早急に評価し, 適切な診断・治療が望まれる. ナルコレプシーや特発性過眠症などの中枢性過 眠症は適切な睡眠状況下であっても覚醒系の障 害により日中の眠気をきたすが，高歯者で日中 の眠気がみられる場合には睡眠の量・質・タイ ミングに異常はないかどうか, 薬物や身体疾患 などによる影響を考慮する必要がある。図 1 に 不眠症の診断・治療・連携ガイドラインの中の 診断ガイドラインを示す ${ }^{3)}$.

本稿では特に高齢者でみられる不眠の特徵と
原因，高齢者の睡眠障害において鑑別を要する 睡眠時無呼吸症候群，レストレスレッグス症候 群，レム睡眠行動異常症について，また各病態 の治療について概説する.

\section{1. 加歯令に伴う睡眠の変化}

睡眠と覚醒の調節は, 覚醒時間の長さによっ て睡眠時間や質が規定されるホメオスタシス(プ ロセスS) と生体内の睡眠覚醒に関与する概日リ ズム（プロセスC）により調節されるとする 2 プロセスモデルがある4). 覚醒時間が延長するに つれて眠気が強くなることや，一日のうちで眠 くない時間帯があること, 眠気のピークの時間 帯を過ぎると眠くなくなること，などはこのた めと考えられる。このホメオスタシスおよび概 日リズム機構は加龄によって変化する，後述す る, 高齢者における深睡眠の減少, 浅睡眠の増 加はホメオスタシス機構（睡眠圧）の減弱を示 


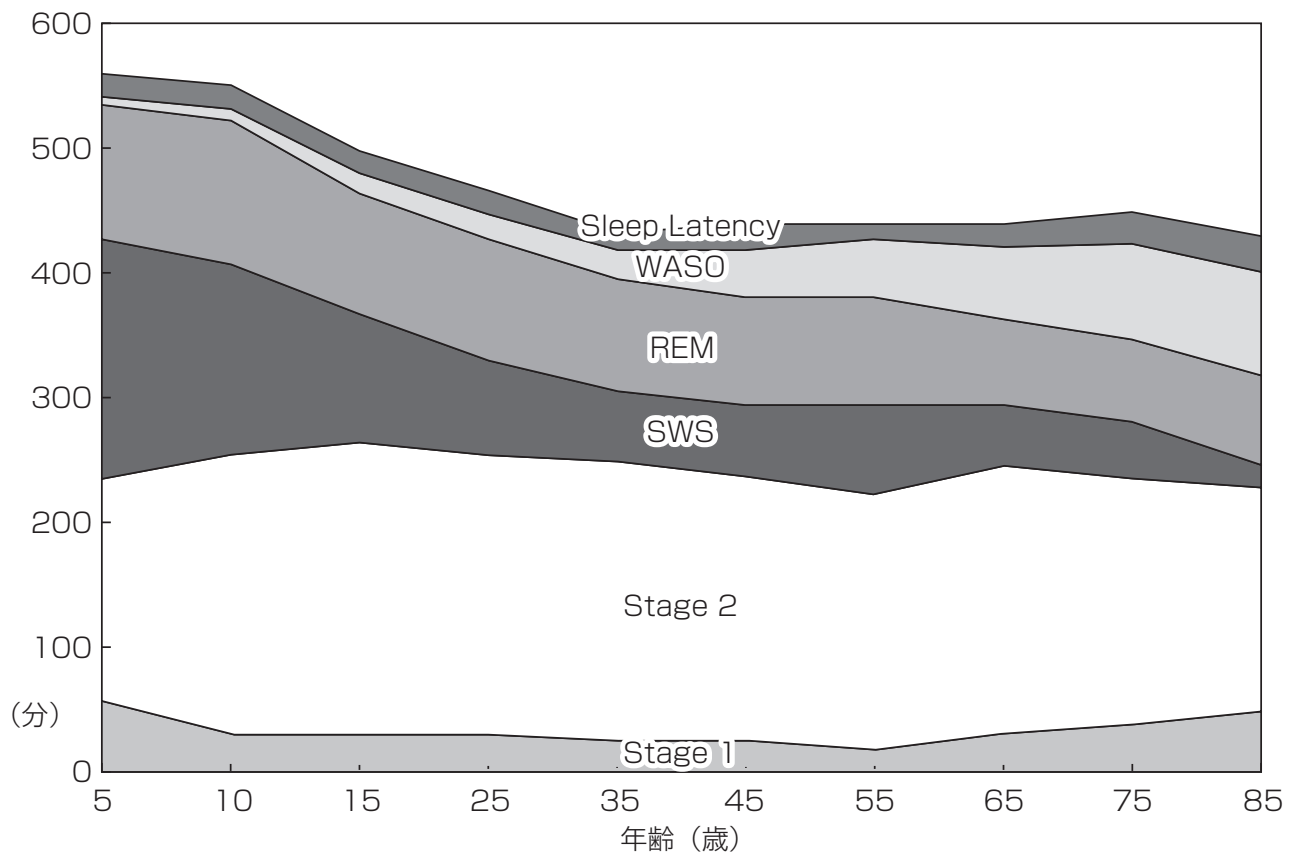

図 2. 健常者における年齢と睡眠時間との関係（文献 6 より引用）

睡眠時間 $=$ Stage 1 （睡眠段階 1), Stage2（睡眠段階 2), SWS (深睡眠), REM (レム睡眠) の合計である

就寝後の覚醒時間＝Sleep latency（睡眠潜時）とWASO（中途覚醒）

し，同調環境下での深部体温の概日リズムや覚 醒時間の前進, 深部体温の概日リズムの振幅減 少は早朝の睡眠を促進する概日シグナルの減少 を反映している5).

\section{1）睡眠構築の変化}

健康な成人では夜間に睡眠が開始されてから まずノンレム睡眠stage 1，2(浅睡眠)からstage 3，4 (深睡眠）と次第に深くなる. 通常レム睡 眠はノンレム睡眠開始 80 分以降に出現し,その 後約 90 分周期に出現する.このような睡眠構築 は睡眠ポリグラフ検査によって確認できる. 年 齢とともに, 総睡眠時間, 睡眠効率, 深睡眠や レム睡眠の割合は減少し, 睡眠潜時, ノンレム 睡眠stage1，2 は増加する (図 2$)^{6)}$. 特に 60 歳以 降では睡眠効率が減少する. 寝床についてから 睡眠に入るまでの睡眠潜時は加齢とともに増加 するが，その変化はわずかであり，20歳と 80
歳を比較したときに差は 10 分未満である.これ らの背景から，高齢者では若年者に比べて総睡 眠時間と深い睡眠が減り, 浅い睡眠が増え, 睡 眠効率 (実際に寝た時間/ベッドにいる時間) が 悪化する。

\section{2）睡眠相の変化}

内因性の概日リズムを形成するペースメーカー は視床下部の視交叉上核に存在し,メラトニン, 深部体温, 睡眠覚醒リズムを調節している。 日 中は覚醒度を上昇させ，夜間は睡眠を促すよう に概日リズムの機構は働くが, 高齢者では覚醒 時刻が前進し, 概日リズムの深部体温の振幅が 低下する。このことから高齢者では睡眠構築の 変化により浅睡眠の増加に加えて, 概日リズム の脆弱化に関連して睡眠相の前進が起こる. 
表 1． 不眠症の一般的基準（睡眠障害国際分類第 2版 2) より）
A. 入眠困難, 睡眠維持困難, 早朝覚醒, 慢性的に回復感のない, 質のよくない睡眠が続くと訴える.
B. 眠る機会や環境が適切であるにもかかわらず上述の睡眠障害が生じる.
C．夜間睡眠の障害に関連して，以下のような日中障害を少なくとも 1 つ報告する.
i ）疲労または倦急感
ii ）注意力，集中力，記憶力の低下
iii）社会生活上あるいは職業生活上の支障，または学業低下
iv）気分がすぐれなかったり，いらいらする（気分障害または焦燥感）
v）日中の眠気
vi）やる気, 気力, 自発性の減退
vii）職場で，または運転中に，過失や事故を起こしやすい
viii）睡眠の損失に相応した緊張，頭痛，または胃腸症状が認められる
ix）睡眠について心配したり悩んだりする

\section{2. 高齢者における不眠症}

不眠症とは睡眠に関する訴えが，適切な睡眠 の環境下において通常 1 力月以上持続し, 日中 の疲労, 集中力や気力の低下, 眠気や気力の低 下を伴うと定義される $(\text { 表 } 1)^{2}$. 主な不眠のタイ プとしては入眠困難，中途覚醒，早朝覚醒や熟 眠感の欠如があり, 高齢者では睡眠相の前進や 深睡眠の減少により，中途覚醒，早朝覚醒や熟 眠感の欠如を訴える場合が多い.

5,407 人 (平均 63 歳) を対象にした疫学調査で は, 男性・女性ともに高年齢は睡眠時間の減少, 睡眠効率の低下, 頻回の中途覚醒がみられた7). 男性では高年齢は浅睡眠の増加と深睡眠の減少 と関連したのに対し，女性では高年齢は睡眠段 階との関連は明らかではなかったが，睡眠に関 する訴え（入眠困難，中途覚醒や早朝覚醒）と 関連していた. 47 歳〜69 歳の 13,563 人を対象に した大規模調查では, 不眠の訴えは入眠困難 $22 \%$, 睡眠維持困難 39\%, 熟眠感の欠如 35\% であり, 年歯令の増加は睡眠維持困難と関連したが, 入眠 困難や熟眠感の欠如とは関連しなかった ${ }^{8)}$. 他に 内科疾患やうつ病の併存, 低所得は不眠の訴え の増加と関連がみられた。

また，不眠の心身への影響として，抑うつや
不安, 生活の質の低下を引き起こし, その状態 が続くと，身体・精神活動へ悪影響を及ぼす. 高齢者においても，総睡眠時間の減少，睡眠効 率の低下や中途覚醒の増加, 浅く分断された睡 眠は歩行スピードの低下，握力低下と関連し， 椅子からの立ち上がりや狭い幅の歩行などのパ フォーマンスに悪影響を与えた ${ }^{9)}$. 重要な影響と して, 不眠は注意力, 反応時間の遅延や記憶障 害といった認知機能の低下との関わりがみられ る. 睡眠時間の減少は, 睡眠導入薬の影響を差 し引いても，転倒リスクと関連すると報告され ている ${ }^{10)}$. 入院中の高齢者を対象に睡眠ポリグラ フ検査を施行した研究では睡眠時無呼吸の合併 は心血管系に関連，またはあらゆる原因による 死亡率の増加と関連していた ${ }^{11)}$.

\section{1）不眠と関連する嗜好品・薬物}

就寝前のアルコールの摂取は睡眠の分断を引 き起こし, 不眠の原因となるほか, 睡眠時無呼 吸を悪化させる．就寝前のニコチンやカフェイ ンの摂取についても不眠の原因になりうる。薬 物では選択的セロトニン再取り込み阻害薬, MAO (monoamine oxidase) 阻害薬, 三環系抗うつ薬, 気管支拡張薬, $\beta$ 拮抗薬, 精神刺激薬などの併用 も不眠を引き起こす原因となる。

2）不眠と関連する身体疾患

多くの慢性疾患の合併は不眠の原因となる. 
うつ病, 心疾患, 体の痛みや記憶障害は不眠症 によく関連すると報告されている ${ }^{12)}$.これらの疾 患は高齢者では併存する場合が多いため, 不眠 との関連についての問診は重要である。他に, かゆみ，咳，頻尿なども不眠を起こす原因とな る。また高齢者においては以下の原発性睡眠障 害などの合併にも注意が必要である。

\section{3. 原発性睡眠障害}

\section{1）レム睡眠行動異常症}

レム睡眠行動異常症（RBD：rapid eye movement sleep behavior disorder) はレム睡眠に生じ る睡眠時随伴症である。睡眠中に逃れようとし たり，争ったりする夢に関連した行動異常，夢 の行動化が起こり, 患者自身やベッドパートナー が負傷する場合がある ${ }^{13)}$. 夜間の異常行動をきた す疾患の鑑別としててんかん, 夜間せん妄, 低 血糖を含む代謝性意識障害などがあげられる， 主な鑑別点として，原則としてRBDの場合は刺 激による覚醒は速やかであり, 夢の再生 (dream recall) が可能である。しかし，てんかん，夜間 せん妄など意識障害の場合には刺激による覚醒 は困難であり，夢の再生も不可能である。睡眠 ポリグラフ検查にて，レム睡眠期に正常では骨 格筋の筋緊張の抑制がみられるが，RBD患者で は筋緊張の抑制の障害(RWA：REM sleep without atonia）がみられる．診断には睡眠ポリグラ フ検査にてRWAとレム睡眠中の異常行動が観察 されるか, あるいは病歴から異常行動のエピソー ドの聴取が必要である，RBDのスクリーニング にはRBDスクリーニング問診票 (5 点以上でRBD 疑い）が有用である（図 3 $)^{14)}$ 。特発性RBDは中 高年の男性（85\% 以上）に多くみられる。特発 性RBD患者の追跡調査により Parkinson病関連疾 患を含む神経変性疾患を発症する例が海外から 報告されており, Parkinson病関連疾患発症前の 治療介入の可能性について注目されているが,
特発性RBD患者が全例神経変性疾患を発症する わけではなく，現段階で神経変性疾患の発症を 予測することは困難である。また三環系抗うつ 薬，選択的セロトニン再取り込み阻害薬，ノル アドレナリン・セロトニン再取り込み阻害薬な どの薬物がRBDを誘発することもある.

治療として,クロナゼパム $0.25 \sim 0.5 \mathrm{mg}$ 就寝前 投与が有効である。高齢者では特に翌日への持 越しに注意し少量から投与する。他に抑肝散や プラミペキソールが有効な症例もある.

\section{2）睡眠時無呼吸症候群}

睡眠時無呼吸症候群（SAS : sleep apnea syndrome）は睡眠関連呼吸障害のひとつであり, 上 気道の部分的または完全閉塞による閉塞性呼吸 イベントを主体とする閉塞性SAS (OSAS) と, 心不全や脳血管障害など中枢性機序の関与によ り呼吸努力の一過性停止による中枢性呼吸イベ ントを主体とする中枢性SAS (CSAS) がある.

OSASでは, 反復する動脈血酸素飽和度低下と 覚醒反応による睡眠の分断化がみられ，不眠， 睡眠中の窒息感の他に, 夜間頻尿, 日中の眠気 や倦怠感, 抑うつ, 起床時頭痛など様々な症状 を引き起こす。一般人口における有病率に関し て, Youngらの報告では無呼吸低呼吸指数 $(\mathrm{AHI})$ 5/h以上は男性 $24 \%$ ，女性 $9 \%$ であり，AHI 5/ h以上に加えて日中の眠気を認めたのは男性 $4 \%$, 女性 $2 \%$ であった ${ }^{15)}$. 本邦からの報告は簡易検査 で, AHI 5 以上は $60 \%$, AHI 15 以上は $22 \%$ で あり, AHI 5 以上で日中の過眠症状をみとめるの は $17 \%$ であった16).

OSASの発症には肥満, 加齢, 顎顔面形態異常 (小下顎，下顎後退)，耳鼻科的要因 (狭咽頭腔, 長口蓋垂，扁桃肥大）なども関連している。 日 本人では欧米に比べて，肥満の割合は低いが, SASの有病率は欧米と同等に高く, 体重増加に対 する上気道の脆弱性や顎顔面形態異常の関与が 考えられている.

OSASは高血圧, 糖尿病, 肥満, 心血管疾患や 


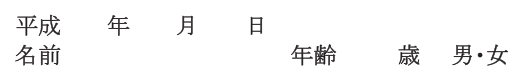

下記のいずれかに○をつけてから、回答をお願いします。

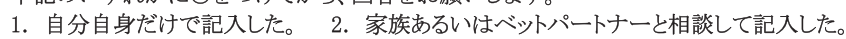

RBD スクリーニング問診票
答え

1. とてもはっきりした夢をときどき見る。

はい・いいえ

2. 攻撃的だったり、動きが盛りだくさんだったりする夢をよく見る。

はい・いいえ

3. 夢を見ているときに、夢の中と同じ動作をすることが多い。

はい・いいえ

4. 寝ている時にうでや足を動かしていることがある。

はい・いいえ

5. 寝ている時にうでや足を動かすので、隣で寝ている人にケガを負わせたり、自分 がケガをしたりすることもある。

はい・いいえ

6. 夢を見ているときに以下のできごとが以前にあったり、今もある。

6.1 誰かとしやべる、大声でどなる、大声でののしる、大声で笑う。

はい・いいえ

6.2 うでと足を突如動かす/ けんかをしているように。

はい・いいえ

はい・いいえ

はい ・ いいえ

はい・いいえ

はい・いいえ

はい・いいえ

9. 眠りがよく妨げられる。

10. 以下のいずれかの神経系の病気を、以前患っていた、または現在患って ますか。(例:脳卒中、頭部外傷、パーキンソン病、むずむず脚症候群、ナルコレプ シー、うつ病、てんかん、脳の炎症性疾患)
はい・いいえ

図 3.RBDスクリーニング問診票日本語版 ${ }^{14)}$

5 点以上でレム睡眠行動異常症 (RBD) 疑い

脳血管障害のリスクと関連している. 中等症以 上のOSASは脳血管障害の独立した危険因子とな る可能性があり ${ }^{17)}$, 高齢者においても重症OSAS $(\mathrm{AHI} \geq 30 / \mathrm{h})$ は脳血管障害の独立した危険因子 であった ${ }^{18)}$. OSASの治療は, 睡眠ポリグラフ
（PSG）検査が必須にて確定診断のうえ, AHI 20 以上では, 経鼻的持続陽圧呼吸 (nasal continuous positive airway pressure : nCPAP) 療法が 第 1 選択となる. 軽〜中等症例 $(5 \leq \mathrm{AHI}<20)$ で は口腔内装置（oral appliance：OA）, 体位依存 
表 2. レストレスレッグス症候群の診断基準 20)

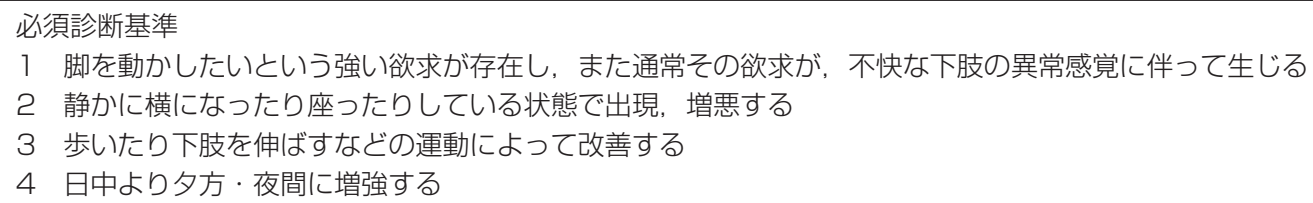

4 日中より夕方・夜間に増強する

\section{診断を補助する特徵}

1 レストレスレッグス症候群の家族歴の存在

2 ドパミン作動薬への反応性が良好

3 睡眠ポリグラフ検査における周期性四肢運動の存在

性に呼吸イベントがみられるときは側臥位就寝 を勧める.CPAP治療により，心血管疾患による 死亡率の低下, 高次脳機能の改善が報告されて

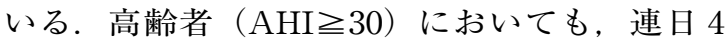
時間以上のCPAP使用により心血管疾患による死 亡率の減少が報告されている ${ }^{19)}$.

\section{3）レストレスレッグス症候群}

レストレスレッグス症候群 (restless legs syndrome：RLS) は夜間安静時に, 異常感覚を伴う, 脚を動かしたくてたまらない衝動のために，不 眠，とくに入眠障害や中途覚醒を引き起こす身 体疾患に由来する不眠のひとつである.

診断には国際レストレスレッグス症候群研究 グループによる 4 項目が用いられ，診断を支持 する所見として, RLSの家族歴の存在, ドパミン 作動薬による治療効果, 周期性四肢運動の存在 がある (表 2 ${ }^{20)}$ ．RLSと鑑別を有する疾患・病 態としてアカシジア，睡眠関連こむらがえり， 末梢神経障害, 神経根症, 骨関節痛, 姿勢によ る不快感，下肢血行障害，painful legs and moving toes，不安障害・うつなどがある ${ }^{20)}$. 病態と して，脳内眝蔵鉄の欠乏とその利用障害，A11 ドパミン神経系の機能異常のほか遺伝的要因の 関与も考えられている. RLS患者の 8 割以上に周 期性四肢運動がみられ，中途覚醒の原因となる 場合がある.

治療はまず非薬物治療として, 睡眠衛生の改
善, 就寝前にカフェイン , ニコチン, アルコー ル摂取を控えるよう指導する.抗精神病薬, SSRI (selective serotonin reuptake inhibitor), 三環系 抗うつ薬，抗ヒスタミン薬，リチウムなどの薬 物がRLS症状を惹起している場合があるため, 内 服薬の確認と必要時には調整を行う。鉄欠乏性 貧血など鉄欠乏を明らかに有する場合や，血清 フェリチン值が $50 \mu \mathrm{g} / \mathrm{l}$ 未満の場合には鉄剤を補 充する. 週 2 回以上RLS症状を有する場合やRLS により日常生活に支障をきたす場合などは薬物 療法の良い適応となる. RLSの第一選択となるの はドパミン作動薬である. RLSに本邦で保険適応 があるドパミンアゴニストはプラミペキソール とロチゴチンである.プラミペキソールは 0.125〜 $0.75 \mathrm{mg}$ を就寝 1 3 時間前に内服投与する. ロチ ゴチンは持続型の貼付製剂であり, 2.25〜 $6.75 \mathrm{mg}$ を使用する，ロチゴチンは日中症状がある場合 に適している。レボドパ製剤は半減期が短く, 後に増強現象などの副作用が生じる可能性があ るため，間欠的投与あるいは短期投与に留める ことが望ましい. ガバペンチンのプロドラッグ であるガバペンチン エナカルビルはRLSに保険 適用があり，特に痛みや不安感を有する症例に 有効である．他に就寝前のクロナゼパム少量も 用いられる。 
表 3. 睡眠衛生のための指導内容（文献 21，22 を参考に改変）

\begin{tabular}{|c|c|}
\hline 指導項目 & 指導內容 \\
\hline 定期的な運動 & $\begin{array}{l}\text { 定期的に運動する. 適度な有酸素運動をすれば㾛つきがよくなる. } \\
\text { 早朝や夕方に行うと睡眠が深くなり，睡眠の質が向上する. 寝る直前の運動は控える }\end{array}$ \\
\hline 寝室環境 & 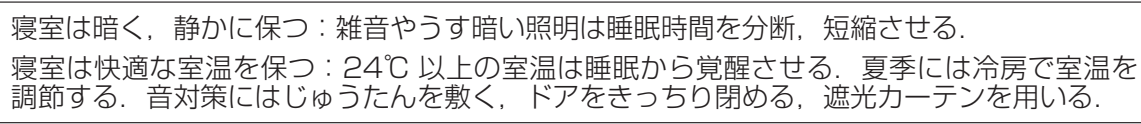 \\
\hline 規則正しい食生活 & 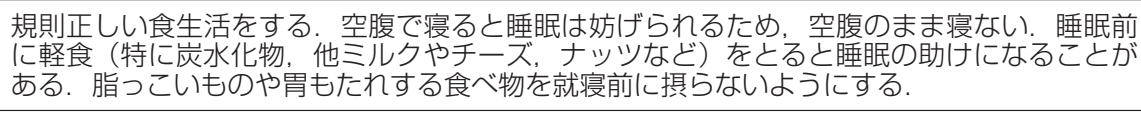 \\
\hline 就寝前の水分 & $\begin{array}{l}\text { 就寝前に水分を取りすぎないようにする。就寝前の水分制限により夜中のトイレ回数が減る. } \\
\text { 脳梗塞や狭心症など血液循環に問題のある場合は主治医の指示に従う. }\end{array}$ \\
\hline 就寝前のカフェイン & 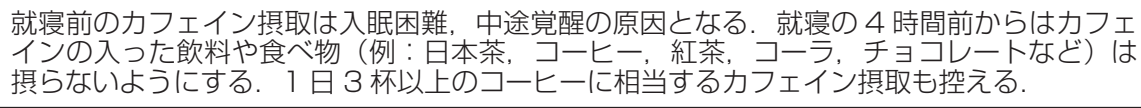 \\
\hline 就寝前の飲酒 & $\begin{array}{l}\text { 眠るための飲酒は逆効果. アルコールを飲むと一時的に寝つきが良くなるが, 徐々に効果は } \\
\text { 弱まり, 夜中に目が覚めやすくなる. 深し眠りも減る. }\end{array}$ \\
\hline 就寝前の喫煙 & 夜の喫煙は避ける. ニコチンには精神刺激作用がある. \\
\hline 寝床での考え事 & 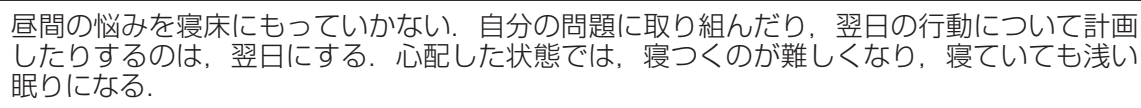 \\
\hline
\end{tabular}

\section{4. 認知症の睡眠障害}

Alzheimer病は概日リズムを司る視交叉上核の 変性や睡眠調節機構の障害により, 日没症候群 (sundowning syndrome)，夜間せん妄をきたす。 健常高齢者と比較して, レム睡眠・深睡眠の減 少, sleep stage 1 の増加, 睡眠紡錘波, K complex の減少が睡眠ポリグラフ検査上みられる．睡眠 相が前進している場合には，昼夜のリズムをつ けて，日中はよく運動し，夕方，日光浴をする， 午睡を 15 時以前にとる，などを行う。また，認 知症，認知機能障害のある高齢者では睡眠に関 する訴えを明確に伝えられず, RLS, SASなどの 睡眠障害の合併が不眠の原因となっている場合 もある．治療に関しては睡眠衛生指導をまず行 う。薬物療法を行う場合には，睡眠の状態を過 小評価している可能性も念頭に置き，翌日への 持越しに注意し，筋弛緩作用が少なく，転倒リ スクの少ない非ベンゾジアゼピン系睡眠薬（Z drug）やラメルテオンが中心となる

\section{5. 高齢者の不眠症の治療}

\section{1）非薬物療法}

不眠は前述の通り，生活の質を著しく低下さ せるため早期発見と治療が必要である。まず, 併存する内科疾患やストレス，不安，抑うつ状 態を含めた精神状態の不眠への関与, さらに嗜 好(アルコール，カフェイン，ニコチン)，常用 薬の関与も確認する。不眠に伴い, 食欲, 意欲, 気分の低下などを伴い，うつ病が疑われる場合 には心療内科・精神科への受診を勧める. 表 3 にまず試みるべきである睡眠衛生の指導を示 す21,22)。主に睡眠環境の整備 (寝室の音, 照度, 温度, 湿度), 就寝前の水分, カフェイン，アル コールの制限，日中運動をして規則正しい時間 に睡眠をとるなどの指導を行う。非薬物療法と して, 刺激制御, 睡眠制限の他, リラクゼーショ ントレーニング，また施行できる施設は限られ 
表 4. 高齢者における睡眠障害の非薬物療法（文献 5 より己改変引用）

刺激制御

眠いときのみベッドで眠るように指示. 20 分経っても眠れないときには寝室から出て，また眠くなったら寝室へ行く． 起床時刻は通常（毎日定刻）通りとし，午睡は避ける。

睡眠制限

自分で予想した総睡眠時間を寝室で過ですようにする。毎週睡眠効率(睡眠時間/ベッド上で過でした時間)を評価する.

睡眠効率が改善してきたら, ベッド上の時間を増やしてもよい.

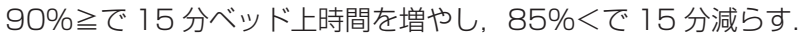

午睡は避ける

睡眠衛生指導

睡眠歴から，効果のない睡眠習慣や睡眠の質を罒化させる行動を正し，睡眠を己攵善させる．午睡は最低限にする．睡眠 を妨げる刺激物の摂取や活動を避ける

カフェイン, 二コチン, アルコール, 重い食事, 過度の水分摂取, 不安な考え, 時計を見ることなど

認知行動療法

睡眠に関する誤った認識を見出し，睡眠に関する認識や関連する行動や感情を修正する.

リラクゼーショントレーニング

賏想，筋弛緩，バイオフィードバック法なよ゙による身体的，認知的覚醒の軽減

逆説的意図

暗く静かな寝室で, ベッド上で横になりできる限り眼を開けて覚醒するように指示.

高照度光療法

睡眠相の前進や早朝覚醒のある場合, 夕方に外の自然光を浴びたり, 高照度光療法を施行

表 5. 本邦で使用可能な主な睡眠薬（文献 23 を参考に改変）

\begin{tabular}{|c|c|c|c|c|}
\hline 種類 & 一般名 & 商品名（®) & 用量（mg） & 半減期（時間） \\
\hline \multirow[t]{5}{*}{ 超短時間型 } & ゾルピデム* & マイスリー & $5-10$ & 2 \\
\hline & ゾピクロン* & アモバン & 7.5-10 & 4 \\
\hline & エスゾピクロン* & ルネスタ & 1-3（高齢者 1-2） & 成人 5 \\
\hline & & & & 高齢者 7 \\
\hline & トリアゾラム & ハルシオン & $0.125-0.25$ & $2-4$ \\
\hline \multirow[t]{4}{*}{ 短時間型 } & エチゾラム & デパス & $\begin{array}{l}\text { 0.5-1 } \\
\text { (一日量 } 3 \text { mgまで) }\end{array}$ & 6 \\
\hline & ブロチゾラム & レンドルミン & 0.25 & 7 \\
\hline & リルマザホン & リスミー & $1-2$ & 10 \\
\hline & ロルメタゼパム & エバミール, ロラメット & $1-2$ & 10 \\
\hline \multirow[t]{3}{*}{ 中間型 } & フルニトラゼパム & ロヒプノール, サイレース & $0.5-2$ & 24 \\
\hline & エスタゾラム & ユーロジン & $1-4$ & 24 \\
\hline & ニトラゼパム & ベンザリン, ネルボン & $5-10$ & 28 \\
\hline \multirow[t]{2}{*}{ 長時間型 } & クアゼパム & ドラール & $15-30$ & 36 \\
\hline & フルラゼパム & ダルメート, ベノジール & $10-30$ & 65 \\
\hline メラトニン受容体アゴニスト & ラメルテオン & ロゼレム & 8 & $1-2 ※$ \\
\hline
\end{tabular}

*非ベンゾジアゼピン系 (z drug)

※作用時間は血中半減期と一致しない 
るが，睡眠に関する誤った認識や行動，感情を 修正する認知行動療法がある（表 4).

\section{2）薬物療法}

本邦で使用可能な睡眠導入薬を表 5 に示す23). 睡眠薬は，入眠困難に対しては超短時間型や短 時間型, 中途覚醒や早朝覚醒に対しては中・長 時間作用型といった使い分けをする。半減期が 一日以上となる中・長時間作用型の使用の際に は翌日への持越しや日中の眠気に注意が必要で ある。現在主にベンゾジアゼピン系睡眠薬と非 ベンゾジアゼピン系睡眠薬が用いられている.

双方ともに脸内GABAA（type-A gammaaminobutyric acid）受容体のベンゾジアゼピン 系受容体に結合し催眠作用を発揮する。ベンゾ ジアゼピン系受容体は $(\omega 1, \omega 2) 2$ 種類あり, $\omega 1$ は催眠作用, $\omega 2$ は抗不安, 筋弛緩作用に関与 する．非ベンゾジアゼピン系睡眠薬は頭文字を とりZ drugとも呼ばれ (eszopiclone, zopiclone, zaleplon, zolpidem：表 5 の* に相当), $\omega 1$ 受容 体への選択性が高いため転倒などの副作用が少 ない. ベンゾジアゼピン系睡眠薬の副作用とし て，急な睡眠薬の中断の際に反跳性不眠がみら れることがある。半減期の短い睡眠薬で起こり やすいため, 中止する際には少量ずつの漸減が 望ましい。他に，半減期が長い睡眠薬では翌日 への持越しや，投与量が多いときには前向性健 忘がみられる場合がある。そのため睡眠薬を飲 んだらすぐに就寝するように指導する。非べン ゾジアゼピン系睡眠薬（Z drug）は，ベンゾジ アゼピン系睡眠薬に比べて長期服用での依存り スクは低いと報告されている. ラメルテオンは 視交叉上核に存在するメラトニン受容体に作用 して睡眠を誘発する。ベンゾジアゼピン系睡眠 薬で見られる可能性のある副作用はない。不眠 症は高歯者に多い病気であり，睡眠薬は多くの 高齢者に用いられている. 多数の臨床試験によ り，睡眠薬投与により高齢者の不眠が改善する ことは明らかになっているが, 高齢者では薬物
代謝・排泄機能が若年者に比べて低下しており， 薬物の副作用が起きやすいことから, 夜間の転 倒, 骨折には注意する必要がある。特に夜間の トイレ歩行時には点灯を心がけるとともに, こ のような点から，高齢者では非ベンゾジアゼピ ン系睡眠薬 $(Z \mathrm{drug})$ の使用が推奨されている ${ }^{22}$. また睡眠導入薬は少量から，単剤を原則に用い る. 常用量でも効果がない場合には睡眠環境の 確認, 内科精神科疾患の合併, 実際の睡眠状態 と不眠の訴えの解離があるかどうかなどの確認 が重要である.

\section{おわりに}

加齢に伴う睡眠の変化とともに，高齢者にお ける不眠症の原因や治療について概説した。本 稿が日常診療における不眠の診療に少しでも役 に立つことができれば幸いである。

著者のCOI (conflicts of interest) 開示: 平田幸一; 講演料 (エーザイ, 大塚製薬, グラクソ・スミスクライン, ノバルティ スファーマ)

\section{文献}

1) Kim K, et al: An epidemiological study of insomnia among the Japanese general population. Sleep $23: 41-47$, 2000.

2) American Academy of Sleep Medicine: International Classification of Sleep Disorders : diagnostic and coding manual, 2nd ed, 2005 (日本睡眠学会診断分類委員会 (訳)： 睡眠障害国際分類第 2 版). 東京 : 医学書院 2010:1-33.

3）山寺 亘, 他 : 不眠症の診断・治療・連携ガイドライン 睡眠医療 $2: 285-289,2008$.

4）日本睡眠学会認定委員会一睡眠障害診療ガイド・ワーキン ググループ監修：睡眠障害診療ガイド，文光堂，東京， 2011.

5) Ancoli-Israel S, Shochat T: Insomnia in older adults. Kryger M, et al, eds. Principles and Practice of Sleep Medicine, 5th edn, Saunders, Philadelphia, 2010, 1544-1550.

6) Ohayon MM, et al: Meta-analysis of quantitative sleep parameters from childhood to old age in healthy individuals: developing normative sleep values across the human lifespan. Sleep 27 : 1255-1273, 2004.

7) Unruh ML, et al : Subjective and objective sleep quality 
and aging in the sleep heart health study. J Am Geriatr Soc 56 : 1218-1227, 2008.

8) Phillips B, Mannino D : Correlates of sleep complaints in adults:the ARIC Study. J Clin Sleep Med 1: 277-283, 2005.

9) Dam TT, et al : Association between sleep and physical function in older men : the osteoporotic fractures in men sleep study. J Am Geriatr Soc 56 : 1665-1673, 2008.

10) Stone KL, et al : Actigraphy-measured sleep characteristics and risk of falls in older women. Arch Intern Med 168 : 1768-1775, 2008.

11) Morimoto $\mathrm{S}$, et al : Sleep apnoea syndrome as a risk for mortality in elderly inpatients. J Int Med Res 40: 601-611, 2012.

12) Foley D, et al : Sleep disturbances and chronic disease in older adults : results of the 2003 National Sleep Foundation Sleep in America Survey. J Psychosom Res 56 : 497502, 2004.

13）宮本雅之, 他：レム睡眠行動障害（異常症). Current Therapy $29: 46-51,2011$.

14) Miyamoto $T$, et al: The REM sleep behavior disorder screening questionnaire : validation study of a Japanese version. Sleep Med 10 : 1151-1154, 2009.

15) Young $\mathrm{T}$, et al: The occurrence of sleep-disordered breathing among middle-aged adults. N Engl J Med 328 : 1230-1235, 1993.

16) Nakayama-Ashida $Y$, et al : Sleep-disordered breathing in the usual lifestyle setting as detected with home monitoring in a population of working men in Japan. Sleep 31 : 419-425, 2008

17) Arzt M, et al : Association of sleep-disordered breathing and the occurrence of stroke. Am J Respir Crit Care Med 172 : 1447-1451, 2005.

18) Munoz R, et al: Severe sleep apnea and risk of ischemic stroke in the elderly. Stroke 37 : 2317-2321, 2006.

19) Martinez-Garcia MA, et al: Cardiovascular mortality in obstructive sleep apnea in the elderly : role of long-term continuous positive airway pressure treatment: a prospective observational study. Am J Respir Crit Care Med 186: 909-916, 2012.

20）宮本雅之, 他：睡眠関連運動障害. 最新精神医学 16 : 673-682, 2011.

21) Edinger JD, et al : Psychological and behavioral treatments for insomnia II : implementation and specific populations. Kryger M, et al, eds. Principles and Practice of Sleep Medicine, 5th edn, Saunders, Philadelphia, 2010, 884-904.

22) 厚生労働科学研究班・日本睡眠学会ワーキンググループ : 睡眠薬の適正な使用と休薬のための診療ガイドライン. 2013.

23）睡眠障害の診断・治療ガイドライン研究会 (代表 : 内山 真)：睡眠障害の対応と治療ガイドライン. じほう, 東京, 2002 . 